Wydziat Nauk Spolecznych

Uniwersytet Gdański

\title{
Kierunki badań prowadzonych przez pracowników Zakładu Historii Nauki, Oświaty i Wychowania Instytutu Pedagogiki Uniwersytetu Gdańskiego
}

\section{Wprowadzenie}

Początki rozwoju gdańskiej historii wychowania przypadają na 2 poł. lat 50 . XX w. i są ściśle związane z osobą ówczesnego doc. dra Kazimierza Kubika, wykładowcy założonej w 1946 r. Państwowej Wyższej Szkoły Pedagogicznej (od 1952 r. - Wyższej Szkoły Pedagogicznej) w Gdańsku. W oparciu o dorobek późniejszego prof. dra K. Kubika i jego współpracowników doprowadzono do utworzenia z dniem 1 października 1959 r. Katedry Historii Oświaty i Wychowania na Wydziale Filologiczno-Historycznym WSP w Gdańsku. W 1969 r. - w związku z odgórnie narzuconymi regulacjami - Katedra ta została zreorganizowana i przekształcona w Zakład Historii Oświaty i Wychowania (ZHOiW), który w ówczesnym kształcie został włączony w strukturę Instytutu Pedagogiki i Psychologii gdańskiej WSP. Od 1970 r. ZHOiW stał się jedną z jednostek podległych Uniwersytetowi Gdańskiemu, powstałemu w wyniku fuzji WSP w Gdańsku z Wyższą Szkołą Ekonomiczną w Sopocie ${ }^{1}$.

Stanowisko pierwszego kierownika Zakładu sprawował - wspomniany - prof. dr K. Kubik (funkcję tę piastował w latach 1959-1980). Jego następcą został prof. dr hab. Klemens Trzebiatowski (lata 1980-1983)². Krótko przed śmiercią prof. K. Trzebiatow-

1 R. Grzybowski, Pięćdziesięciolecie gdańskiej historii wychowania, „Biuletyn Historii Wychowania” 2008, t. 24, s. 140-142; zob. J. Żerko, Profesor Kazimierz Kubik (1910-1986) pionier i organizator środowiska naukowego historyków oświaty $i$ wychowania w Gdańsku, w: Oświata, wychowanie i kultura fizyczna w rzeczywistości spoleczno-politycznej Polski Ludowej (1945-1989). Rozprawy i szkice, pod red. R. Grzybowskiego, Toruń 2004, s. 359-369.

2 R. Grzybowski, Gdańska pedagogika i historia wychowania w latach 1945-1980. Struktury, twórcy $i$ realizowane przez nich kierunki badań, w: Tradycje gdańskiej humanistyki, pod red. J. Borzyszkowskiego i C. Obracht-Prondzyńskiego, Gdańsk 2008, s. 350-353. 
skiego Zakład na wiele lat objął uczeń prof. K. Kubika - ówczesny dr hab. Lech Mokrzecki (późniejszy prof. dr hab., dr h.c. Uniwersytetu w Linköping) ${ }^{3}$. Prof. L. Mokrzecki kierował omawianą jednostką w latach 1983-2005. Uwzględniając profil badań przez niego prowadzonych w 1 poł. lat 80 . XX w. została zmieniona dotychczasowa nazwa Zakładu, który od tego czasu nosi nazwę Zakładu Historii Nauki, Oświaty i Wychowania (ZHNOiW). Po przejściu prof. L. Mokrzeckiego na emeryturę, ZHNOiW przejął dr hab. Romuald Grzybowski ${ }^{4}$ (obecnie profesor tytularny).

W przeciągu niespełna 60. lat istnienia Zakładu jego skład osobowy niejednokrotnie ulegał zmianom. Oprócz wyżej wymienionych profesorów, w różnych okresach działalności, etatowymi pracownikami ZHNOiW byli: dr Jerzy Szews, dr Józef Żerko, dr Witold Wierzbicki, prof. nadzw. dr hab. Lidia Burzyńska-Wentland, dr Tomasz Maliszewski, mgr Jerzy Szmytka, dr Henryk Rostek, dr Janina Siwoszko, mgr Małgorzata Lachowicz-Strugała, mgr Zofia Anikiej, dr Anna Tomkiel. W 1 poł. lat 50. z Zakładem związany był prof. dr hab. Bolesław Pieśniarski. W ramach zatrudnienia na drugim etacie (lub części etatu) z Zakładem współpracowali: doc. dr hab. Wiktor Frąckowiak, prof. dr hab. Karol Toeplitz, dr Walenty Aleksandrowicz, dr Zdzisław Piątek. Przez kilka lat w strukturze Zakładu umocowano także prof. dr. hab. Marcina Tomczaka - dyrygenta Chóru Uniwersytetu Gdańskiego.

Obecnie w Zakładzie Historii Nauki Oświaty i Wychowania Instytutu Pedagogiki Uniwersytetu Gdańskiego pracuje ośmiu badaczy. Oprócz wspomnianego prof. dr. hab. Romualda Grzybowskiego (zatrudnionego na UG w latach 1981-1988 i ponownie od 2005 r.), są nimi: prof. dr hab. Krzysztof Jakubiak (od 2007 r.); dr hab. Kazimierz Puchowski, prof. nadzw. (od 1983 r.); dr hab. Jacek Taraszkiewicz, prof. nadzw. (od 1987 r.); dr Mariusz Brodnicki (od 2004 r.); dr Elżbieta Gorloff (od 2007 r.); dr Andrzej Kołakowski (od 2007 r.) $)^{5}$ d dr Paweł Śpica (od 2011 r.).

\section{Glówne kierunki prowadzonych badań od lat 50. XX w. do początków XXI w.}

Gdańscy historycy wychowania od lat 50. XX w. prowadzili, zainicjowane przez prof. K. Kubika, badania nad przeszłością naukową i oświatową Gdańska, koncentrując się zwłaszcza na działalności Gdańskiego Gimnazjum Akademickiego. Już w początkach istnienia Katedry Historii Oświaty i Wychowania w obszarze ich zainteresowań znalazła się też problematyka edukacji dzieci i młodzieży polskiej w Prusach Zachodnich w obliczu germanizacyjnej polityki władz pruskich (szczególnie w 2 poł. XIX w. i w pocz. XX w.), a także rozwój szkolnictwa w Polsce, w województwie pomorskim i na pogra-

\footnotetext{
${ }^{3}$ Por. K. Puchowski, J. Żerko, Profesor Lech Marian Mokrzecki - badacz dziejów nauki, kultury i oświaty, w: W stużbie historii nauki, kultury i edukacji. Księga pamiatkowa dedykowana prof. Lechowi Mokrzeckiemu z okazji jubileuszu pięćdziesięciolecia pracy zawodowej, pod red. R. Grzybowskiego i T. Maliszewskiego, Gdańsk 2006, s. 17-24.

${ }^{4}$ R. Grzybowski, Pięćdziesięciolecie..., s. 146.

5 Ibidem, s. 154-163.
} 
niczu polsko-niemieckim w dwudziestoleciu międzywojennym. Ponadto pracownicy Zakładu prowadzili badania nad najnowszymi dziejami oświaty i wychowania zarówno w ujęciu lokalnym, jak i ogólnopolskim, w czym prym wiódł początkowo prof. K. Trzebiatowski. Szczególne osiągnięcia gdańscy historycy wychowania odnotowali również w zakresie badań nad edukacją morską ${ }^{6}$.

Jak zauważa Romuald Grzybowski, profil badań prowadzonych przez pracowników Zakładu ustabilizował się w latach 70. i 80. XX w. Z kolei w latach 90. i w pocz. XXI w. dotychczasowa problematyka badawcza została wzbogacona o nowe obszary. Prof. L. Mokrzecki oraz jego uczniowie - obecny dr hab. K. Puchowski i dr hab. J. Taraszkiewicz - szczególnie rozwinęli badania nad edukacją w okresie staropolskim. Ich dociekania naukowe koncentrują się wokół problematyki: nauczania historii, szkolnictwa protestanckiego i katolickiego w XVI, XVII i XVIII w. ze szczególnym uwzględnieniem Prus Królewskich; kształcenia i wychowania elit politycznych I Rzeczypospolitej; a także dziejów nauki oraz rozwoju poszczególnych dyscyplin naukowych w Gdańsku?

Gdańscy historycy wychowania rozwinęli też badania nad edukacją dzieci i młodzieży polskiej w Prusach Zachodnich w okresie zaborów. W tym względzie niewątpliwie zasłużył się dr Jerzy Szews, autor m.in. prac poświęconych filomatom pomorskim, nauczaniu języka polskiego i tajnym związkom młodzieży polskiej na Pomorzu Gdańskim w XIX i w pocz. XX w. ${ }^{8}$ Tematykę rozwiniętą przez dr. J. Szewsa kontynuowała następnie dr Lidia Burzyńska-Wentland (obecnie doktor habilitowana, zatrudniona w Akademii Marynarki Wojennej w Gdyni), autorka publikacji poświęconych m.in. strajkom szkolnym dzieci polskich w Prusach Zachodnich w latach 1906-1907.

$\mathrm{Z}$ kolei badania nad najnowszymi dziejami oświaty, w tym przemianami ideałów wychowawczych i rozwojem szkolnictwa w Polsce w okresie PRL-u, które zapoczątkował prof. K. Trzebiatowski i dr J. Żerko, obecnie kontynuuje i znacząco rozwija prof. R. Grzybowski i jego uczniowie.

W latach 90. XX w. i w pierwszych latach dwutysięcznych pracownikiem ZHNOiW był też dr T. Maliszewski, który zajmuje się m.in. problematyką edukacji pozaszkolnej, historii i działalności uniwersytetów ludowych, a także kształcenia dorosłych w Polsce i w Europie (szczególnie zaś w Szwecji) . Na uwagę zasługują również badania prowadzone po 2000 r. przez mgr Annę Paszkowską (obecnie dr A. Tomkiel), która podjęła się tematyki rozwoju szkolnictwa podstawowego w województwie gdańskim w latach 1945-1975.

\footnotetext{
${ }^{6}$ Por. ibidem, s. 142-143; zob. L. Mokrzecki, Współczesne kierunki badań nad dziejami oświaty i nauki $w$ środowisku gdańskim i ich najnowsze wyniki, w: Historia wychowania w XX wieku. Dorobek i perspektywy, pod red. T. Gumuły, J. Krasuckiego, Kielce 1998, s. 515-525; idem, Historia wychowania w Gdańsku z perspektywy pięćdziesięciolecia (1946-1996), „Ars Educandi” 2000, t. 2, s. 19-33.

${ }^{7}$ R. Grzybowski, Pięćdziesięciolecie..., s. 143-144.

8 J. Żerko, Bibliografia prac naukowych dra Jerzego Szewsa 1962-2009, w: Z badań nad dziejami oświaty i polskiego życia narodowego na Pomorzu Nadwiślańskim w XIX i XX wieku. Księga pamiatkowa dedykowana doktorowi Jerzemu Szewsowi z okazji jubileuszu 85. rocznicy urodzin, pod red. L. Burzyńskiej-Wentland, Gdańsk 2010, s. 37-59.

${ }_{9}$ R. Grzybowski, Pięćdziesięciolecie..., s. 144-145.
} 
Wyrazem aktywności naukowej gdańskich badawczy jest także redagowana przez nich od 2010 r. seria wydawnicza „Szkoła-Państwo-Społeczeństwo” (dotychczas składająca się z ośmiu tomów), jak również organizowane konferencje i sympozja, spośród których warto wymienić te najnowsze, tj.: „Szkoła, państwo, społeczeństwo - między autonomią a podległością. Konferencja naukowa z okazji 50-lecia ZHNOiW” (2009), „Sympozjum naukowe z okazji jubileuszu 85. urodzin dra Jerzego Szewsa” (2011), „Być nauczycielem w PRL-u...” (2012), „Wyzwania, nadzieje, perspektywy - dzieciństwo i młodość w Polsce w czasach przełomów (1918-1989)” (2014), „Sympozjum naukowe z okazji 80. urodzin prof. Lecha Mokrzeckiego" (2015), a także planowana do realizacji w 2017 r. konferencja nt. „Być uczniem w szkole polskiej z lat 1918-1989”.

\title{
Zainteresowania naukowe, główne osiągnięcia i kierunki badań prowadzonych przez obecnych pracowników Zakładu
}

\author{
Prof. dr hab. Romuald Grzybowski - kierownik Zakładu
}

Zainteresowania naukowe prof. R. Grzybowskiego koncentrują się wokół szeroko rozumianej problematyki dziedzictwa edukacyjnego PRL-u. Prowadzone przez niego badania dotykają zagadnień, takich jak: kształcenie nauczycieli w liceach pedagogicznych i studiach nauczycielskich (SN-ach) funkcjonujących na terenie województwa gdańskiego w latach 1945 - 1975; dzieje i dorobek szkół wyższych w Polsce w latach 1946 1956 i dalszych; polityczne, ideologiczne i organizacyjne uwarunkowania rozwoju socjalistycznej szkoły polskiej z lat PRL-u, ze szczególnym uwzględnieniem tendencji do urzędowej laicyzacji jej struktur organizacyjnych i ateizacji realizowanego w niej wychowania dzieci i młodzieży; nauczyciel socjalistycznej szkoły polskiej z lat PRL- u, jego indoktrynacja wpisana $\mathrm{w}$ system doskonalenia zawodowego pedagogów $\mathrm{z}$ tego okresu; dziecko i rodzina w socjalistycznym systemie oświatowym oraz podejmowane wobec nich działania propagandowe i pedagogiczne; młodzież polska z lat PRL-u i proces jej socjalizacji przebiegającej w warunkach ostrego konfliktu politycznego i społecznego; założenia i rozwój socjalistycznej pedagogiki polskiej w okresie stalinowskim oraz początki i rozwój pedagogiki gdańskiej; biograficzny wymiar rozwoju pedagogiki polskiej po 1945 r.; sytuacja oświaty polskiej w Prusach Zachodnich w okresie zaborów, a zwłaszcza problemy wychowania patriotycznego dzieci w rodzinie polskiej. Spośród najważniejszych prac prof. R. Grzybowskiego należy wymienić: Studia nauczycielskie w województwie gdańskim w latach 1955-1970. Ich rozwój i efekty kształcenia, Gdańsk 1994; Wyższe Szkoły Pedagogiczne w Polsce w latach 1946-1956, Gdańsk 2000, Polityczne priorytety i elementy codzienności socjalistycznej szkoły. Wybór studiów poświęconych dziedzictwu edukacyjnemu PRL-u, Toruń 2013, a także książki pod redakcją, m.in. Oświata, wychowanie i kultura fizyczna $w$ rzeczywistości społeczno-politycznej Polski Ludowej (1945-1989). Rozprawy i szkice, Toruń 2004 i Zaangażowanie? Opór? Gra? Szkic do portretu nauczyciela w latach PRL-u, Toruń 2013. 


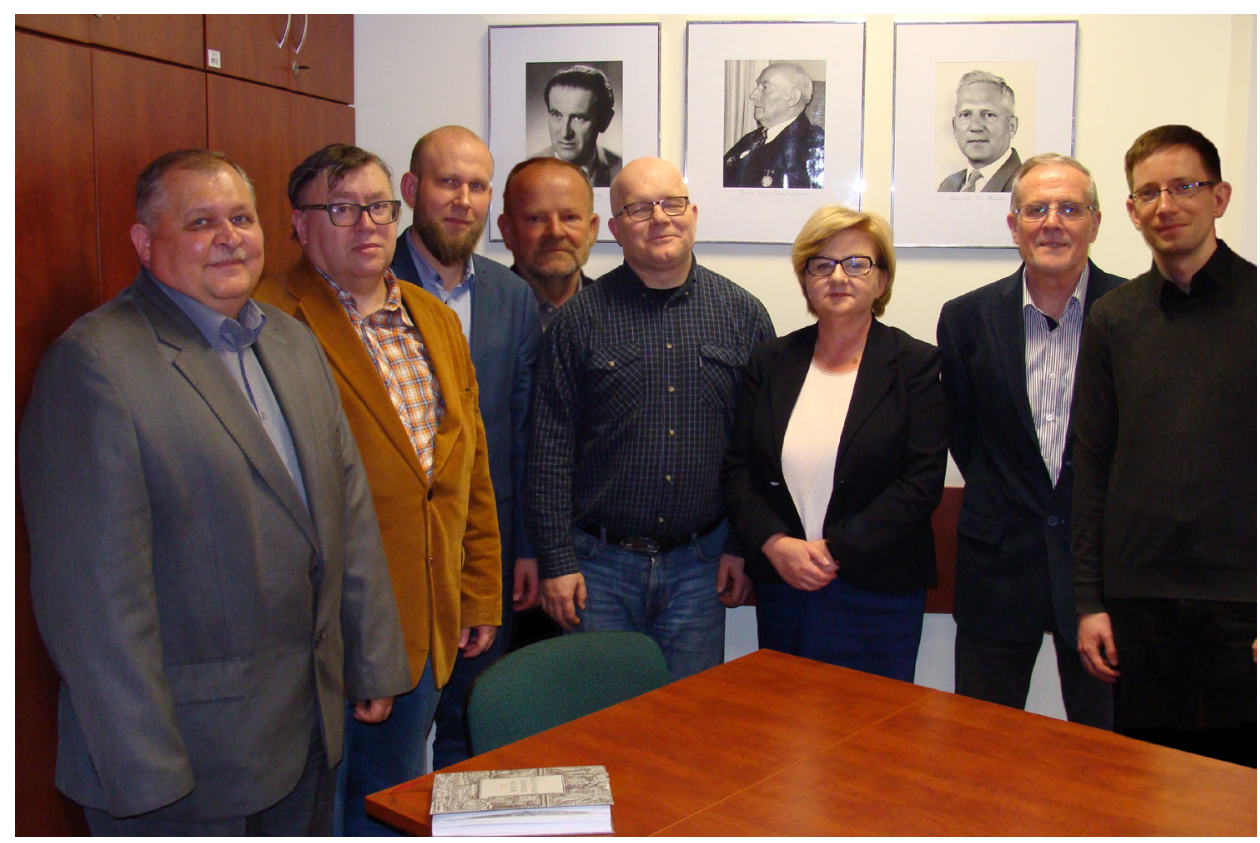

Pracownicy Zakładu Historii Nauki, Oświaty i Wychowania Instytutu Pedagogiki Uniwersytetu Gdańskiego w roku 2017. Stoją od lewej: Krzysztof Jakubiak, Jacek Taraszkiewicz, Mariusz Brodnicki, Kazimierz Puchowski, Andrzej Kołakowski, Elżbieta Gorloff, Romuald Grzybowski, Paweł Śpica. Gdańsk 5 kwietnia 2017, fot. Paweł Śpica (zdjęcie z samowyzwalacza)

Prof. dr hab. Krzysztof Jakubiak

Prof. K. Jakubiak specjalizuje się w kilku obszarach badawczych. Jest autorem prac poświęconych zagadnieniom związanym z kształtowaniem się ideologii wychowawczych w Polsce w okresie międzywojennym (w tym ideologii wychowawczej ruchu piłsudczykowskiego i pedagogiki katolickiej w II Rzeczypospolitej). Obecnie prof. K. Jakubiak rozwija następującą problematykę: wychowanie rodzinne oraz relacje rodziny i szkoły w polskiej pedagogice oraz praktyce edukacyjnej XIX i XX w. - do 1956 r.; dziecko i dzieciństwo na ziemiach polskich w świetle źródeł narracyjnych XIX i pocz. XX w.; dzieje nauczania domowego w rodzinach polskich od XVIII do pocz. XX w.; wychowanie gospodarcze społeczeństwa II Rzeczypospolitej; idee polskiej pedagogiki romantycznej 1 poł. XIX w. i jej kontekst historyczno-kulturowy. Do najważniejszych prac autorstwa prof. K. Jakubiaka należą m.in.: Wychowanie państwowe jako ideologia wychowawcza sanacji. Ksztattowanie $i$ upowszechnianie $w$ periodycznych wydawnictwach społeczno-kulturowych i pedagogicznych, Bydgoszcz 1994; Współdziałanie rodziny i szkoły w pedagogice II Rzeczypospolitej, Bydgoszcz 1997; a także książki pod redakcją, m.in.: Rodzina jako środowisko wychowawcze w czasach nowożytnych, Bydgoszcz 
1995; Z dziejów wychowania i edukacji w rodzinie, Bydgoszcz 1998; Partnerka, matka, opiekunka. Statut kobiety w dziejach nowożytnych od XVI do XX wieku, Bydgoszcz 2000.

Dr hab. Kazimierz Puchowski, prof. nadzw.

Zainteresowania badawcze prof. K. Puchowskiego koncentrują się wokół działalności oświatowej i wychowawczej jezuitów, pijarów i teatynów w I Rzeczypospolitej, edukacji elit w Europie nowożytnej, szkolnictwa katolickiego i protestanckiego w Prusach Królewskich, a także uwarunkowań kulturowych i społecznych edukacji staropolskiej. Do najważniejszych publikacji prof. K. Puchowskiego należą następujące książki: Edukacja historyczna w jezuickich kolegiach Rzeczypospolitej 1565-1773, Gdańsk 1999; Jezuickie kolegia szlacheckie Rzeczypospolitej Obojga Narodów. Studium z dziejów edukacji elit, Gdańsk 2007 oraz współredagowana wraz z Ludwikiem Piechnikiem $Z$ dziejów Almae Matris Vilnensis. Księga pamiątkowa ku czci 400-lecia założenia i 75-lecia wskrzeszenia Uniwersytetu Wileńskiego, Kraków 1996.

Dr hab. Jacek Taraszkiewicz, prof. nadzw.

Dorobek naukowy prof. Jacka Taraszkiewicza oscyluje wokół różnych aspektów działalności edukacyjnej zakonu pijarów w Rzeczypospolitej Obojga Narodów w XVII i XVIII w. Prof. J. Taraszkiewicz podjął się m.in. przybliżenia początków działalności zakonu pijarów, nauczania historii, wychowania religijnego i edukacji teatralnej w szkolnictwie pijarskim, a także ukazania aktywności oświatowej i wychowawczej pijarów na tle porównawczym (w odniesieniu do szkolnictwa jezuickiego i protestanckiego w Rzeczypospolitej i w Europie). Do najważniejszych publikacji prof. J. Taraszkiewicza należą następujące pozycje: Edukacja historyczna w szkolnictwie pijarskim 1642-1773, Gdańsk 2011 i Pierwsze stulecie zakonu pijarów na ziemiach Rzeczypospolitej Obojga Narodów (1642-1740), Gdańsk 2015.

\section{Dr Elżbieta Gorloff}

Badania prowadzone przez dr E. Gorloff koncentrują się wokół problematyki: przeobrażeń w organizacji i funkcjonowaniu szkolnictwa ogólnokształcącego w województwie gdańskim w okresie PRL-u; sytuacji społeczno-politycznej i zawodowej nauczycieli szkół ogólnokształcących w województwie gdańskim w latach 1945-1956; roli organizacji społecznych i ideowo-wychowawczych w działalności szkół podstawowych w województwie gdańskim w okresie PRL-u; kształcenia, dokształcania i doskonalenia zawodowego nauczycieli szkół podstawowych w Polsce w latach 1945-1989; wyższych szkół nauczycielskich w systemie kształcenia nauczycieli szkół podstawowych 
(1968-1972); nauczania początkowego w PRL-u: koncepcji i reform w obszarze edukacji wczesnoszkolnej, ewolucji wizerunku nauczyciela, kształcenia i doskonalenia zawodowego nauczycieli nauczania początkowego. Do najważniejszych publikacji dr E. Gorloff należy m.in. książka, pt. Polityczne i społeczne konteksty działalności szkolnictwa w Lęborku w latach 1945-1989, Gdańsk 2010, a także wydana pod jej redakcją praca zbiorowa pt. Wzrastać w cieniu historii. Dzieci i młodzież $w$ instytucjach edukacyjnych $w$ Polsce (1918-1989), Toruń 2015.

\section{Dr Andrzej Kołakowski}

Zainteresowania naukowe dr A. Kołakowskiego oscylują wokół problematyki: instytucjonalnej opieki nad dzieckiem w okresie PRL; obrazu opieki nad dzieckiem w czasopiśmiennictwie pedagogicznym w latach 1945-1990; dziecka i dzieciństwa w warunkach państwa totalitarnego. Dr A. Kołakowski jest też autorem m.in. publikacji poświęconych różnym kontekstom relacji młodzież-państwo w PRL-u. Do najważniejszych prac autorstwa dr. A. Kołakowskiego należy m.in. książka pt. Opieka nad dzieckiem sierocym $w$ województwie gdańskim w latach 1945-1956, Gdańsk 2010 oraz wydana pod jego redakcją praca zbiorowa pt. Doświadczenie dzieciństwa i młodości w Polsce (1918-1989), Toruń 2015.

\section{Dr Mariusz Brodnicki}

Na dorobek naukowy dr. M. Brodnickiego składają się m.in. publikacje poświęcone zagadnieniu nauczania filozofii i edukacji przyrodniczej w Gdańskim Gimnazjum Akademickim oraz prace oparte na analizach biografii gdańskich uczonych (XVI-XVIII w.). W ostatnich latach zainteresowania naukowe dr. M. Brodnickiego oscylują też wokół problematyki edukacji żywieniowej. Dr M. Brodnicki jest autorem książki pt. Nauczanie filozofii w Gdańskim Gimnazjum Akademickim do połowy XVII wieku, Gdańsk 2012 oraz współredaktorem licznych prac zbiorowych, m.in. Historia, interpretacja, reprezentacja, Gdańsk 2012 i Gdańskie Gimnazjum Akademickie, t. 5: Źródła i artykuły, Gdańsk 2012. Ponadto opracował wydane w 2016 r. Athenae Gedanenses Ephraima Praetoriusa.

\section{Dr Paweł Śpica}

Zainteresowania naukowe dr. P. Śpicy koncentrują się wokół kilku obszarów, tj.: problematyki wychowania w rodzinach polskich i ich stosunku do edukacji w Prusach Zachodnich w XIX i w pocz. XX w. na tle germanizacyjnej polityki władz pruskich i ścierania się nowoczesnych i ofensywnych nacjonalizmów; roli oświatowo-wychowawczej 
duchowieństwa katolickiego diecezji chełmińskiej w XIX i w 1 poł. XX w.; historii mentalności i kultury ludności polskiej i niemieckiej Pomorza Nadwiślańskiego (w tym zwłaszcza Borów Tucholskich, Kociewia i Kaszub); przemian relacji w rodzinach w Polsce w XX w. i współcześnie (ze szczególnym uwzględnieniem zmiany pozycji i znaczenia ojca w strukturze rodzinnej), jak również edukacji i indoktrynacji młodzieży w organizacjach komunistycznych w latach PRL-u. Dr P. Śpica w bieżącym roku wydaje książkę pt. Powszechna Organizacja „,Stużba Polsce” w województwie gdańskim w latach 1948-1955 - edukacja i indoktrynacja młodzieży.

\section{Konkluzja}

Zakład Historii Nauki Oświaty i Wychowania IP UG, który jeszcze kilka lat temu liczył przeszło dziesięciu pracowników etatowych nadal stanowi silny zespół badawczy, składający się obecnie z czterech samodzielnych pracowników naukowych i czterech adiunktów. Badania prowadzone przez gdańskich historyków wychowania z jednej strony stanowią kontynuację kierunków zainicjowanych w pierwszych dziesięcioleciach istnienia Zakładu (Katedry), a poszerzanych i pogłębianych, z drugiej zaś koncentrują się wokół nowych obszarów (np. zagadnień związanych z historią wychowania w rodzinie). Wydaje się, że jako pracownicy ZHNOiW IP UG możemy się poszczycić już pewną, wypracowaną w ciągu ostatnich 60 lat, tradycją, którą staramy się rozwijać, mimo nie zawsze sprzyjających warunków i okoliczności. 